\title{
CHEK2 1100 delC mutation in Russian ovarian cancer patients
}

\author{
Nadezhda Yu. Krylova', Daria N. Ponomariova ${ }^{2}$, Natalia Yu. Sherina ${ }^{2}$, Natalia Yu. Ogorodnikova ${ }^{2}$, Denis A. Logvinov², \\ Natalia V. Porhanova ${ }^{3}$, Oksana S. Lobeiko², Adel F. Urmancheyeva', Sergey Ya. Maximov' ${ }^{2}$ Alexandr V. Togo², \\ Evgeny N. Suspitsin ${ }^{2,4}$, Evgeny N. Imyanitov ${ }^{1,2,4}$ \\ 'Medical Academy of Postgraduate Studies, Sankt Petersburg, Russia \\ 2N.N. Petrov Institute of Oncology, Sankt Petersburg, Russia \\ ${ }^{3}$ Regional Oncological Hospital, Krasnodar, Russia \\ ${ }^{4}$ Sankt Petersburg Pediatric Medical Academy
}

Key words: $B R C A 1, B R C A 2$, Ovarian cancer, screening

Corresponding author: Evgeny N. Imyanitov, N.N. Petrov Institute of Oncology, Pesochny-2, 197758 Sankt Petersburg, Russia, phone: +781259689 51,fax: +78125968947; e-mail: evgeny@imyanitov.spb.ru

Submitted: 23 July 2007

Accepted: 7 September 2007

\begin{abstract}
BRCA1 and BRCA2 germ-line mutations occur in a significant number of unselected ovarian cancer (OC) patients, thus making a noticeable contribution to $O C$ morbidity. It is of interest whether CHEK2, which is frequently regarded as a third breast cancer specific gene, is also relevant to ovarian cancer pathogenesis. In this report we analyzed the presence of CHEK2 1100 delC founder mutation in 268 randomly recruited OC patients. The mutation was identified in 2 women with $\mathrm{OC}(0.8 \%)$ as compared to $1 / 448(0.2 \%)$ healthy middle-aged and 0/373 elderly tumour-free women. Taken together this result and the negative findings of two other published reports on an association of CHEK2 with ovarian cancer indicate that there is no justification for intensive ovarian cancer screening in CHEK2 1100 delC carriers.
\end{abstract}

\section{Introduction}

A close relationship between breast and ovarian cancer risks has been recognized by physicians for a considerable period of time. Not surprisingly, both "classical" breast cancer (BC) predisposing genes, BRCA 1 and BRCA2, turned out to be strongly associated not only with $B C$, but also with ovarian cancer $[1,2]$. The third BC-associated gene, CHEK2, appeared to be relevant to ovarian cancer since it was observed that $4 / 99(4.0 \%)$ carriers of the inactive $1100 \mathrm{del} C$ allele were present among the index cases from breast-ovarian cancer families as compared to only 18/1620 (1.1\%) CHEK2 heterozygotes in control subjects [3]. While the role of CHEK2 in breast cancer predisposition has subsequently been proven $[4,5]$, there are only two published reports analyzing the relevance of $1100 \mathrm{del} C$ to ovarian cancer risk. Baysal et al. [6] found no CHEK2 inactivating alleles in 751 unselected ovarian cancer cases, but detected one 1100 delC heterozygote (1.9\%) among 52 familial OC patients; 521 control subjects contained 3 carriers $(0.6 \%)$ of the defective allele. Szymanska-Pasternak et al. [7] also failed to detect truncating CHEK2 variants in 209 ovarian cancer patients, while $0.7 \%$ of 4000 control subjects had an inactive copy of this gene.

The distribution of the CHEK2 1100 delC allele shows wide geographical variation; therefore only a few countries in the world are suitable for casecontrol studies on the pathological significance of the 
CHEK2 1100delC variant. The CHEK2 1100 delC allele was recently shown to be relevant to the incidence of breast cancer in Sankt Petersburg (Russia);

Table 1. Clinical characteristics of the ovarian carcinoma patients

\begin{tabular}{ccc}
\hline Groups & Number & (\%) \\
\hline Age (years) & & \\
\hline$\leq 40$ & 34 & 12.7 \\
\hline $41-60$ & 160 & 59.7 \\
\hline$\geq 61$ & 74 & 27.6 \\
\hline
\end{tabular}

\begin{tabular}{lcc}
\hline \multicolumn{3}{l}{ Mean age: 53.1 years } \\
\hline Age range: $21-89$ years & & \\
\hline T status & & \\
\hline$T=1$ & 44 & 16.4 \\
\hline$T>1$ & 211 & 78.7 \\
\hline Non-informative & 13 & 4.9 \\
\hline
\end{tabular}

\begin{tabular}{lcc}
\hline $\mathrm{N}$ status & & \\
\hline $\mathrm{N}=0$ & 101 & 37.7 \\
\hline $\mathrm{N}=1$ & 52 & 19.4 \\
\hline $\mathrm{Nx}$ & 102 & 38.1 \\
\hline Non-informative & 13 & 4.9 \\
\hline
\end{tabular}

\begin{tabular}{lcc}
\hline$M$ status & & \\
\hline$M=0$ & 174 & 64.9 \\
\hline$M=1$ & 55 & 20.5 \\
\hline$M x$ & 22 & 8.2 \\
\hline Non-informative & 13 & 4.9 \\
\hline Tumour differentiation & & \\
\hline Grade 1 & 35 & 13.1 \\
\hline Grade 2 & 73 & 27.2 \\
\hline Grade 3 & 160 & 59.7 \\
\hline Histology & & \\
\hline Serous adenocarcinoma & 235 & 87.7 \\
\hline Mucinous adenocarcinoma & 8 & 3.0 \\
\hline Adenocarcinoma, unspecified & 14 & 5.2 \\
\hline Other & 10 & 3.7 \\
\hline Non-informative & 1 & 0.4 \\
\hline Total & 268 & 100.0 \\
\hline
\end{tabular}

therefore we reasoned that this population would be valuable in the evaluation of its frequency in ovarian cancer patients residing in the same city [8].

\section{Materials and methods}

The study included 268 ovarian cancer patients undergoing treatment in N.N. Petrov Institute of Oncology (Sankt Petersburg, Russia). The relevant characteristics of the cases are presented in Table 1. The healthy control population has already been described by Chekmariova et al. [8] and Buslov et al. [9]; it included 448 middle-aged female donors and 373 elderly tumour-free women. CHEK2 $1100 \mathrm{delC}$ genotyping was performed by real-time allele-specific PCR. Primers were TTG GAG TGC CCA AAA TCA GT (specific for the wild-type allele), CTT GGA GTG CCC AAA ATC AT (specific for the mutated allele) and CTG ATC TAG CCT ACG TGT CT (common primer). The PCR mix included approximately $50 \mathrm{ng}$ genomic DNA, 1 unit heat-activated Taq DNA polymerase, $1 \times$ PCR buffer (pH 8.3), $1.5 \mathrm{mM} \mathrm{MgCl} 2,200 \mu \mathrm{M}$ dNTP, $0.5 \mu \mathrm{M}$ each primer, and $0.5 \times$ SYBR Green I in a final volume of $10 \mu \mathrm{l}$. PCR amplification and product detection were carried out using the $\mathrm{i} C y c l e r i Q$ Real Time Detection System (Bio-Rad) for 50 cycles $\left(95^{\circ} \mathrm{C}\right.$ for $35 \mathrm{sec}$., $57^{\circ} \mathrm{C}$ for $30 \mathrm{sec}$, $72^{\circ} \mathrm{C}$ for $30 \mathrm{sec}$.) after an initial activation of the polymerase at $95^{\circ} \mathrm{C}$ for $8 \mathrm{~min}$. For each batch of assays control wild-type and mutation-positive DNA samples were included. The specificity of the 120-bp PCR product was confirmed by DNA melting curve analysis. All mutation-positive cases as well as some randomly selected DNA specimens were also subjected to conventional allelespecific PCR (35 cycles in the same conditions) followed by restriction fragment detection by polyacrylamide gel electrophoresis.

\section{Results}

CHEK2 1100 delC was identified in $2(0.8 \%)$ out of 268 ovarian cancer patients. One of the 1100 delC mutation positive patients, who was 67-years-old, presented with an early stage (TINOMO) tumour that had serous adenocarcinoma histology (grade 2). The second patient was 66-years-old; the tumor was also a serous adenocarcinoma (grade 1), but the stage of disease was significantly more advanced (T3NxM1). Neither of the affected females reported a family history of breast or ovarian cancer. The BRCA7 5382insC mutation, which appears to be the most frequent mutation in unselected Russian ovarian cancer patients, was analyzed in 266 patients. From the 266 women, 

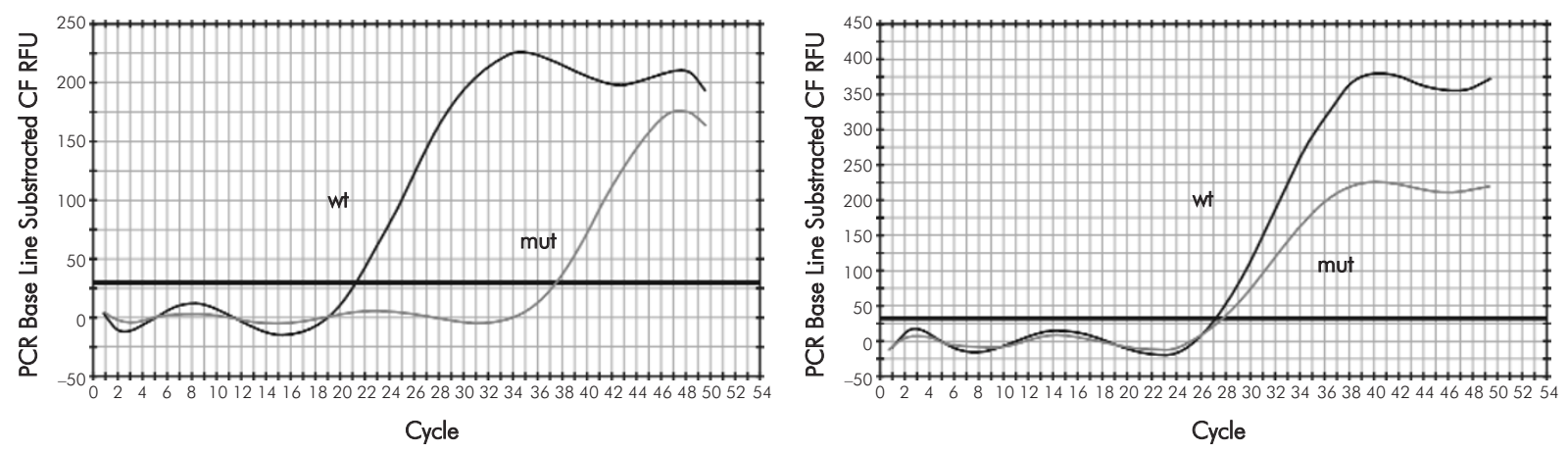

Fig. 1. Detection of CHEK2 1100 delC mutation by real-time allele-specific PCR. When normal DNA is subjected to PCR, the amplification driven by the wild-type specific primer significantly exceeds that initiated by mutation-specific oligonucleotide (left). In the case of CHEK2 1100 delC heterozygosity, both wild-type and mutation-specific curves cross their threshold of detection at approximately the same cycle (right)

22 (8.3\%) BRCA7 5382insC heterozygotes were identified and there were no instances of a simultaneous occurrence of CHEK2 1100delC and BRCA1 5382insC alleles.

CHEK2 1100 delC mutation was detected in 1/448 (0.2\%) healthy middle-aged females and in none of 373 elderly tumour-free women [8]. None of the statistical tests demonstrated a significant difference, although a formal trend to an association was revealed when comparing the occurrence of CHEK2 $1100 \mathrm{delC}$ variant in ovarian cancer patients against elderly controls $(p=0.095)$.

\section{Discussion}

The most studied and well recognized breast/ovarian cancer genes, BRCA1 and BRCA2, show a distinct distribution in breast and ovarian cancer patients. In breast cancer, the probability of finding a BRCAl or BRCA2 mutation is increased when $B C$ patients are selected for young age of disease onset and/or a family history and/or the presence of multiple primary tumours. In contrast, the selection of patients using these parameters is not justified in ovarian cancer patients: randomly recruited $O C$ usually show a high frequency of BRCA mutations comparable to highly selected cases of $B C$. Furthermore, the trend of a family history or young age of disease onset is less evident in BRCA-associated ovarian cancer compared to breast cancers $[10,11]$.

While BRCA germ-line mutations contribute to a significant proportion of ovarian cancer cases $[10,11]$, it appears that the CHEK2 1100 delC allele is not associated to any extent with ovarian cancer risk $[6,7$, and the present study]. It is an interesting scientific question as to why BRCA 1 and BRCA2, being completely different genes $[1,12]$, predispose to both breast and ovarian tumourigenesis, whereas CHEK2 appears only to alter the risk of BC. It also remains unclear whether some rare cases of non-breast cancer can be somehow triggered by the CHEK2 1100 delC allele, or its presence is absolutely neutral for the tumours developing outside mammary glands. Our data on the absence of the CHEK2 1100 delC variant in elderly tumour-free women suggest that this mutation decreases the probability of achieving old age without cancer. However, although we observed a significant frequency of CHEK2 1100 delC heterozygotes in Russian breast cancer patients $(2.1 \%)$, the occurrence of this allele in the corresponding middle-aged control group is also very low $(0.2 \%)$. Thus, it is unclear whether depletion of CHEK2 1100 delC mutation carriers in middle-aged and elderly controls takes place as a result of an increased likelihood of there being a cancerpredisposing role of this allele, or its low frequency in the control groups is simply attributable to a chance.

Overall, the disease significance of CHEK2 1100 delC is difficult to determine because of the low population frequency, uneven geographical distribution and low cancer penetrance. To resolve these issues will require much larger population-based studies requiring a significant number of cancer patients and tumourfree controls in order to clarify whether organs other than the breast are at risk in CHEK2 1100 delC carriers. Taken together with published data $[6,7]$, the present study does not justify the need for intensive ovarian cancer screening in females bearing the CHEK2 1100 delC allele.

\section{Acknowledgements}

This work is supported by INTAS (grant 051000008-7870), the Russian Agency for Science and Innovations (grant 02.512.11.2101), the Russian 
Nadezhda Yu. Krylova, Daria N. Ponomariova, Natalia Yu. Sherina, Natalia Yu. Ogorodnikova, Denis A. Logvinov, Natalia V. Porhanova, Oksana S. Lobeiko, Adel F. Urmancheyeva, Sergey Ya. Maximov, Alexandr V. Togo, Evgeny N. Suspitsin, Evgeny N. Imyanitov

Federation for Basic Research (grants 07-04-00172-a and 06-04-48139-a) and the Government of Moscow (grant 15/07).

\section{References}

1. Narod SA, Foulkes WD. BRCA1 and BRCA2: 1994 and beyond. Nat Rev Cancer 2004; 4: 665-676.

2. Sowter HM, Ashworth A. BRCA1 and BRCA2 as ovarian cancer susceptibility genes. Carcinogenesis 2005; 26: 1651-1656.

3. Meijers-Heijboer $\mathrm{H}$, van den Ouweland A, Klijn J, Wasielewski M, de Snoo A, Oldenburg R, Hollestelle A, Houben M, Crepin $E$, van Veghel-Plandsoen $M$, Elstrodt $F$, van Duijn C, Bartels $C$, Meijers C, Schutte M, McGuffog L, Thompson D, Easton D, Sodha N, Seal S, Barfoot R, Mangion J, Chang-Claude J, Eccles D, Eeles R, Evans DG, Houlston R, Murday V, Narod S, Peretz T, Peto J, Phelan C, Zhang HX, Szabo C, Devilee P, Goldgar D, Futreal PA, Nathanson KL, Weber B, Rahman N, Stratton MR; CHEK2-Breast Cancer Consortium. Low-penetrance susceptibility to breast cancer due to CHEK2 $\left({ }^{*}\right) 1100$ delC in noncarriers of BRCA1 or BRCA2 mutations. Nat Genet 2002; 31: 55-59.

4. CHEK2 Breast Cancer Case-Control Consortium. CHEK2* $1100 \mathrm{delC}$ and susceptibility to breast cancer: a collaborative analysis involving 10,860 breast cancer cases and 9,065 controls from 10 studies. Am J Hum Genet 2004; 74: 1175 1182.

5. Nevanlinna H, Bartek J. The CHEK2 gene and inherited breast cancer susceptibility. Oncogene 2006; 25: 5912-5919.

6. Baysal BE, DeLoia JA, Willett-Brozick JE, Goodman MT, Brady MF, Modugno F, Lynch HT, Conley YP, Watson P, Gallion HH. Analysis of CHEK2 gene for ovarian cancer susceptibility. Gynecol Oncol 2004; 95: 62-69.

7. Szymanska-Pasternak J, Szymanska A, Medrek K, Imyanitov EN, Cybulski C, Gorski B, Magnowski P, Dziuba I, Gugala K, Debniak B, Gozdz S, Sokolenko AP, Krylova NY, Lobeiko OS, Narod SA, Lubinski J. CHEK2 variants predispose to benign, borderline and low-grade invasive ovarian tumors. Gynecol Oncol 2006; 102: 429-431.

8. Chekmariova EV, Sokolenko AP, Buslov KG, lyevleva AG, Ulibina YM, Rozanov ME, Mitiushkina NV, Togo AV, Matsko DE, Voskresenskiy DA, Chagunava OL, Devilee P, Cornelisse C, Semiglazov VF, Imyanitov EN. CHEK2 1100 delC mutation is frequent among Russian breast cancer patients. Breast Cancer Res Treat 2006; 100: 99-102.

9. Buslov KG, lyevleva AG, Chekmariova EV, Suspitsin EN, Togo AV, Kuligina ESh, Sokolenko AP, Matsko DE, Turkevich EA, Lazareva YR, Chagunava OL, Bit-Sava EM, Semiglazov VF, Devilee P, Cornelisse C, Hanson KP, Imyanitov EN. NBS1 657del5 mutation may contribute only to a limited fraction of breast cancer cases in Russia. Int J Cancer 2005; 1 14: 585-589.

10. Malander S, Ridderheim M, Måsbäck A, Loman N, Kristoffersson U, Olsson $\mathrm{H}$, Nilbert M, Borg A. One in 10 ovarian cancer patients carry germ line BRCA1 or BRCA2 mutations: results of a prospective study in Southern Sweden. Eur J Cancer 2004; 40: 422-428.

11. Pal T, Permuth-Wey J, Betts JA, Krischer JP, Fiorica J, Arango H, LaPolla J, Hoffman M, Martino MA, Wakeley K, Wilbanks G, Nicosia S, Cantor A, Sutphen R. BRCA1 and BRCA2 mutations account for a large proportion of ovarian carcinoma cases. Cancer 2005; 104: 2807-2816.

12. Gudmundsdottir K, Ashworth A. The roles of BRCA1 and BRCA2 and associated proteins in the maintenance of genomic stability. Oncogene 2006; 25: 5864-5874. 